\title{
Developing Learning Devices for Brain Based Learning Model by Using Scientific Approach in Teaching and Learning Biology at Senior High School
}

\author{
Baiq Sri Handayani* \\ Biology Education Study Program \\ Universitas Mataram \\ Mataram, Indonesia \\ sri_baidowi@yahoo.com
}

\author{
Kusmiyati Kusmiyati \\ Biology Education Study Program \\ Universitas Mataram \\ Mataram, Indonesia \\ kusmiyati.fkip@unram.ac.id
}

\author{
Muhlis Muhlis \\ Biology Education Study Program \\ Universitas Mataram \\ Mataram, Indonesia \\ muhlis.ocean@yahoo.co.id
}

\author{
I Putu Artayasa \\ Biology Education Study Program \\ Universitas Mataram \\ Mataram, Indonesia \\ artayasa75@unram.ac.id
}

\author{
I Wayan Merta \\ Biology Education Study Program \\ Universitas Mataram \\ Mataram, Indonesia \\ wayanmerta@unram.ac.id
}

\begin{abstract}
The purpose of this study was to develop learning devices for the Brain Based Learning (BBL) model by using valid, effective, and practical scientific approach. To develop the learning devices, this study adapted Plomp development model, consisting of five stages: (1) preliminary investigation stage, (2) design stage, (3) realization/construction stage, and (4) test, evaluation, and revision stage. The results of this research show that: (1) the characteristics of BBL model with the scientific approach is a model in which visual and verbal language, relaxation and self-reflection are applied; (2) the learning syntax consists of : (a) pre-explanation, (b) preparation (observing and asking), (c) initiation and acquisition (collecting information/experiment), (d) elaboration (discussing and communicating), (e) incubation and insert the memory, (f) verification and checking of confidence, and celebrations and integration; (3) the validation scores for the developed model were: $94.8 \%$, from expert validation $\left(\mathrm{V}_{\mathrm{ah}}\right), 78.9 \%$ from user validation $\left(\mathrm{V}_{\mathrm{pg}}\right)$, and $69.7 \%$ from audience validation $\left(\mathrm{V}_{\mathrm{au}}\right)$ and that the average score from these three scores $(81.1 \%)$ indicates that the developed learning devices for the BBL model has attained the level of effectiveness, i.e.: very valid, very effective, very complete, and ready to use.
\end{abstract}

Keywords - learning device, Brain Based Learning model, scientific approach

\section{INTRODUCTION}

The success of learning is affected by the permanent and non-permanent aspects. The permanent aspect is related to genetic factors and the non-permanent aspect is related to the environment. From these two aspects, the non-permanent aspect in the form of environmental is the key to the success of the learning system because environmental aspects are dynamic and there are human interventions, such as teachers. The teacher as the mainstay for success in learning should think not only those related to the learning material but also how to teach students meaningfully to achieve the learning objectives.

Biology learning in schools is taught through analytic thinking, inductive, and deductive to solve the problem related to natural phenomena around [1]. Hadiprayitno [2] dealing with the problem of learning biology in high school in Lombok found that among the factors causing students have difficulty in learning biology are the teaching style of teacher, the content of biological material, and academic atmosphere. It was also found that $48.63 \%$ of high school biology teachers in Lombok had problems in implementing the learning activities, $28.10 \%$ of them have problems in conducting assessment activities, and $23.37 \%$ of them had problems in planning learning activities.

These problems were partly caused by the use of teaching strategies or methods and learning devices that tend to dominantly involve the left brain. According to Kushartanti, the learning process in schools often focuses only on the outside of the left brain that plays a role in the process of logic, words, mathematics, and the dominant sequence for academic learning [3]. Furthermore, it was said that the right brain associated with the rhythm of music, images, and creative imagination has not received a proportionate part to be developed. Behaviours that emphasize the balance of the right and left brain in learning will make students not trapped in stressful situations because with this balance students can manage the stress so that stress conditions do not become obstacles to the learning process [4].

Currently, learning models related to the work system of the brain have begun to be developed, one of them is the Brain Based Learning (BBL) model. $\mathrm{BBL}$ is a learning model based on the working potential of the brain. According to Bowen, Brain Based Learning (BBL) provides scientific evidence 
that may trigger more brain activity so as to provide information to educators about the most effective learning activities for students [5]. Jensen [6] states the stages of BBL starting from (1) pre-explanation, (2) preparation, (3) initiation and acquisition, (4) elaboration, (5) incubation and insert the memory, (6) verification and checking of confidence, and (7) celebrations.

Some of the research results that support the effectiveness of BBL in learning are: (1) the use of learning methods based on brain work can naturally improve student learning achievement [7]; (2) students can perform better when students are not feeling threatened [8]; (3) The use of BBL can improve students' mastery of concepts [9]-[11]; (4) The use of BBL can increase learning motivation and attitude of science [12].

The compiling of the learning device using BBL models should be adapted to the existing learning curriculum in school. There are some high schools in Lombok using the 2013 curriculum with the scientific approach. The scientific approach is not a method but learning steps that can be integrated with other learning strategies or models. The steps of the scientific approach according to Government Regulations of the Ministry of Education and Culture No. 81/2013 consists of 5 steps: observing, asking questions, collecting information/experiments, and communicating.

BBL as one of the brain-based learning models needs to be integrated with the scientific approach. The purpose of the integration is to produce a new model that can be used as an alternative to improve the quality of learning in schools. The learning model is realized in the form of syntax and learning devices.

Based on the description above, one of the ways to solve the learning problems in Lombok is by combining the Brain Based Learning (BBL) model with the scientific approach. The purpose of this research was to develop learning devices for the Brain Based Learning (BBL) by using valid, effective, and practical scientific approach.

\section{METHOD}

The development of learning devices for the BBL model by using the scientific approach followed the stages adapted from the Plomp development model [13] which consists of five stages: (1) preliminary investigation stage, (2) design stage, (3) realization/construction stage, and (4) test, evaluation, and (5) revision stage.

The entire process of developing the learning devices of BBL learning model using scientific approach adapted from the Plomp [13] model is briefly presented in Table 1 .
TABLE 1. Stages of BBL MODEL DEVELOPMENT WITH SCIENTIFIC APPROACH

\begin{tabular}{|c|c|}
\hline Stages & Activities \\
\hline \multirow{3}{*}{$\begin{array}{l}\text { Stage I } \\
\text { Preliminary } \\
\text { Investigation }\end{array}$} & Finding information about learning \\
\hline & $\begin{array}{l}\text { Providing rational reason about the } \\
\text { development model of the BBL with } \\
\text { scientific approach }\end{array}$ \\
\hline & $\begin{array}{l}\text { Studying the theories that underlie the } \\
\text { development model of the BBL with } \\
\text { scientific approach }\end{array}$ \\
\hline \multirow[t]{5}{*}{$\begin{array}{l}\text { Stage II } \\
\text { Design }\end{array}$} & $\begin{array}{l}\text { The rational model of BBL with scientific } \\
\text { approach }\end{array}$ \\
\hline & Designing the social systems \\
\hline & Designing the principle of reaction \\
\hline & Designing the support system \\
\hline & The impact of learning \\
\hline \multirow{2}{*}{$\begin{array}{l}\text { Stage III } \\
\text { Realization/Construction }\end{array}$} & Arranging the learning syntax \\
\hline & Arranging the learning device \\
\hline \multirow{2}{*}{$\begin{array}{l}\text { Stage IV } \\
\text { Test, Evaluation, and } \\
\text { Revision }\end{array}$} & Device validation \\
\hline & The field trials in limited class \\
\hline $\begin{array}{l}\text { Stage V } \\
\text { Implementation }\end{array}$ & $\begin{array}{l}\text { The field trials in comprehensive class. The } \\
\text { activities is conducted in the form of Quasi } \\
\text { Experiment study, conducted in } 2020 \text {. }\end{array}$ \\
\hline
\end{tabular}

The learning devices developed were in the form of syllabus, lesson plans, teaching materials, and student worksheet. The instruments for collecting the data needed are: (1) Teacher's questionnaire; which aimed to obtain preliminary information related to teaching and learning activities done by the teacher, teachers' understanding of brain-based learning, and the involvement of students in learning. This questionnaire was distributed to 13 high school teachers in the city of Mataram; (2) Validation sheets for developed product, which consists of syllabus validation sheets, lesson plans, teaching materials, and student worksheet. This validation sheet was used to obtain validation data from biology learning experts, media experts, and senior teachers in high school on learning devices of BBL model with the scientific approach developed. The results of the validation were calculated by using the formula:

$$
V-a h=\frac{T S e}{T S h} x 100
$$

(3) Questionnaire related to the use of the developed product, which contains indicators that can explore information about teacher' and students' responses to the implementation of learning, teaching materials, and student worksheet that. The results of the questionnaire were calculated by using the formula:

$$
V-p g=\frac{T S e}{T S h} x 100
$$

Test, which aimed to find out the learning outcomes after the implementation of the BBL model with scientific approach in a limited class. The questions were in the form of essay and the results of the test were calculated by using the formula: 


$$
V-a u=\frac{T S e}{T S h} x 100
$$

Further, the results from expert validation, user validation, and test (audience validation) were calculated to know the average result by using the following combined formula:

$$
V=\frac{V_{a h}+V_{p g}+V_{a u}}{3}=\cdots \%
$$

Formula Description:

$V=$ Validation (combined)

$V_{\text {ah }}=$ Expert validation;

$V_{p}$

${ }^{P Q}=$ user validation;

$V_{\text {au }}=$ audience validation

$T_{s e}=$ The achieve of total score empirically (based on expert assessment; the user; the achieved score of competency test results by students

$T_{\text {sh }}=$ The total score expected

Based on the result from the combination of the three components of validation above, a conclusion is drawn by referring to the criteria for the level of validity or effectiveness as described in Table 2.

TABLE 2. CRITERIA FOR EFFECTIVENESS OF LEARNING MODEL

\begin{tabular}{ccl}
\hline No. & $\begin{array}{c}\text { Achievement } \\
\text { Criteria Score } \\
\text { (Effectiveness) }\end{array}$ & \multicolumn{1}{c}{ Effectiveness Level } \\
\hline 1 & $81 \%-100 \%$ & $\begin{array}{l}\text { Very valid, very effective, very } \\
\text { complete, can be used without } \\
\text { improvement }\end{array}$ \\
\hline 2 & $61 \%-80 \%$ & $\begin{array}{l}\text { Very valid, very effective, very } \\
\text { complete, can be used but needs } \\
\text { minor improvements }\end{array}$ \\
\hline 3 & $41 \%-60 \%$ & $\begin{array}{l}\text { less valid, less effective, incomplete, } \\
\text { need major improvement, it is } \\
\text { recommended not to use }\end{array}$ \\
\hline 4 & $21 \%-40 \%$ & $\begin{array}{l}\text { invalid, ineffective, incomplete, } \\
\text { cannot be used }\end{array}$ \\
\hline 5 & $00 \%-20 \%$ & $\begin{array}{l}\text { Very invalid, very ineffective, very } \\
\text { incomplete, very unusable }\end{array}$ \\
\hline & & \multicolumn{1}{c}{ Source: (Akbar, 2015) }
\end{tabular}

The data obtained in this research were preliminary information of learning, expert validation results, user validity, and tests, were analyzed descriptively.

\section{RESULTS AND DISCUSSION}

\section{A. Preliminary Investigation Stage}

Based on the results of questionnaire distributed to teachers, it can be stated that the problems faced by most biology teachers in the city of Mataram are: (a) difficulties in compiling learning devices, (b) difficulties in teaching the abstract material, (c) the ineffective approach used to overcome the students' boredom in learning, (d) the difficulty in applying the scientific approach, (e) that teachers never heard about BBL model and did not know the important elements needed by the brain during the learning, and (f) also teachers never heard classical music during (马)e learning.

Considering the problems stated above, it is important to facilitate in providing the learning devices in the form of syllabus, lesson plans, teaching materials, and student worksheets. The development of the brain-based device that is integrated with the scientific approach can be used as a reference in teaching and learning biology in high schools, especially in the city of Mataram. It is found that the learning is commonly focused on the work of the left brain which associated with logical and mathematical processing, and it ignored the work of the right brain that associated with music, movement, and creative imagination [3]. In this case, Santoso [4] stated that the balance in the use of the right and left brain in learning can make students not trapped in stressful situations, in which the students can manage the stress conditions which can be obstacles in teaching and learning process. In addition, a lot of theoretical studies related to BBL and scientific approaches have been conducted which can become the basis for developing a learning model.

Learning related to the brain work system has begun to be developed, such as the Brain Based Learning (BBL) model. BBL as one of the brainbased learning models is based on five natural brain learning systems consisting of learning systems of emotional, social, cognitive, physical and reflective. Based on the BBL syntax assessment, it was found advantages in which the students are encouraged to drink enough water and make movements, such as easy exercise, to the balance of brain work system, and also students are given the opportunity to think independently, quietly while listening to classical music.

According to Bowen [5], BBL provides scientific evidence that can trigger more brain activity in order to provide information to educators about the most effective learning activities for students. BBL is derived from cognitive neuroscience theory that comes from studies of how the brain works by the neuroscience [8]. There are 12 BBL principles derived from the study of brain work function by neuroscience, including: (a) the brain is a parallel processor, (b) learning is influenced by physiology, (c) the search for meaning is inherent, (d) the search for meaning occurs by imitation, (e) the emotions greatly affect the process of imitation, (f) each brain simultaneously observes and creates the parts and overall knowledge acquired, (g) the learning involves in attention which focuses and wide perception, (h) students always involve conscious and unconscious processes, (i) we have at least two memory systems, (j) the brain understands and remembers very well when reality and ability are united into natural spatial memory, (k) learning is developed by challenges and impeded by threats, and (1) every brain is unique [14]. 
The BBL principles that can improve student achievement in the classroom include: (a) speaking, (b) emotions, (c) vision, (d) interrupting (e) movements, (f) change, (g) the brain needs oxygen, (h) the rest of the brain, (i) establishing relationships, (j ) feedback, (k) music, (l) acronyms, (m) hydration, (n) time for reflection (o) energy levels, (p) space, (q) location, (r) positive environment, (s) ) optimistic, (t) choice, (u) anticipation, and (v) meaningful learning [15].

On the other hand, the scientific approach as one of the characteristics of the 2013 curriculum is learning steps that can be integrated with other learning model or strategy. Susilana [16] found that the impacts of using scientific approach in learning are: (1) it can trigger the creation of a variety of learning experiences obtained by the students; (2) it helps teachers develop more varied learning activities; and (3) it can help create learning process that fulfill the process standards in the implementation of 2013 curriculum.

\section{B. Design Stage}

This stage was dealing with designing learning syntax. The syntax was designed with regard to the class system created to achieve the expected goals. Putrawangsa [17] states that in teaching and learning design, there are elements of change or products to achieve learning objectives. Therefore, the learning design does not stop only at the learning design stage, but also continues at the reconstruction, realization and evaluation stages.

The information to be considered in making the design includes: (a) The BBL as learning model is integrated with the scientific approach implemented in the form of learning devices namely syllabus, lesson plans, teaching materials, and student worksheets; (b) The system created is a learning activity that describes the active interaction between teacher and students, student and student in class discussions, and there are learning instructions given by the teacher; and (c) The supportive learning systems in which the teacher prepares classical music for self-reflection and relaxation activities, materials/textbooks for exploration activities and understanding of knowledge, and student worksheets that have been made and modified based on the BBL model

\section{Construction Stage}

Activities at this stage successfully integrate the BBL models with the scientific approach. The syntax can be described as follows: (a) Pre-explanation, students drink enough water and make movements such as easy exercise to balance the brain; (b) Preparation, students conduct observing and asking questions; (c) Initiation and Acquisition, students conduct activity to collect the information/experimental activity); (d) Elaboration, students conduct discussions and communication activity; (e) Incubating and Inserting Memory, students are given the opportunity to think independently and quietly while listening to classical music; (f) Verification and Testing confidence, students conduct concluding activities with question and answer; and (g) Celebration and Integration, students get rewards and show yells as a form of excitement for success in learning.

Based on its syntax, compared to another learning model, the BBL model has some advantages, such as students are advised to drink enough water and make movements like easy exercise to balance the brain, and students are given the opportunity to think independently and quietly while listening to classical music. Mozart music effects can improve spatial ability, increase alpha wave which has an impact on positive learning ability [18]. Added by Kurniawati, music can improve emotional intelligence, among others students become more relaxed, concentrate, and create comfortable classroom conditions so students can manage their emotions better [19]. According to Handayani \& Corebima, every part of the body which conducted activities such as what is seen, heard, and performed by the body will react to the workings of both hemispheres [20].

In reference to the syntax above, the learning devices developed consist of syllabus, lesson plans, teaching materials, and student worksheet. These learning devices were considered as prototype 1 which was then validated by expert validators and in a limited trial.

\section{Test, Evaluation, and Revision Stage}

The quality of developed learning devices are generally required three criteria, namely: validity, practicality, and effectiveness. Furthermore, an educational product requires to show not only the quality of the learning material, but also the aspect of validity, practicality, and effectiveness so that it can be widely used [21]. For this purpose, the testing for the developed learning device was conducted in limited classes. The activities conducted at this stage are: (a) The device validation activities (prototype 1) by expert validators and then device was revised based on the validation results. The results of these revisions were considered as prototype II devices, and (b) testing the developed product considered as prototype II to get responses from users, such as teachers and students, and also to get the students' cognitive learning outcomes. The followings are the descriptions of the results for each activity.

There were 3 validation results given by experts and the results of the validation analysis can be seen in Table 3. 
TABLE 3. DEVICES VALIDATION RESUlts

\begin{tabular}{|c|c|c|c|c|c|}
\hline \multirow{2}{*}{ Devices } & \multicolumn{3}{|c|}{$\begin{array}{c}\text { Validator Assesment } \\
\text { Results (\%) }\end{array}$} & $\begin{array}{c}\text { Average } \\
(\%)\end{array}$ & Category \\
\cline { 2 - 4 } & 1 & 2 & 3 & & \\
\hline Syllabus & 91.7 & 87.5 & - & 98.6 & $\begin{array}{c}\text { Very } \\
\text { Valid }\end{array}$ \\
\hline $\begin{array}{c}\text { Lesson } \\
\text { Plan }\end{array}$ & 93.2 & 93.2 & - & 93.2 & $\begin{array}{c}\text { Very } \\
\text { Valid }\end{array}$ \\
\hline $\begin{array}{c}\text { Teaching } \\
\text { Materials }\end{array}$ & 95.0 & 94.4 & 94.6 & 94.7 & $\begin{array}{c}\text { Very } \\
\text { Valid }\end{array}$ \\
\hline $\begin{array}{c}\text { Student } \\
\text { Worksheets }\end{array}$ & 95.0 & 90.0 & - & 92.5 & $\begin{array}{c}\text { Very } \\
\text { Valid }\end{array}$ \\
\hline \multicolumn{7}{|c|}{ Average } & $\mathbf{9 4 . 8}$ & $\begin{array}{c}\text { Very } \\
\text { Valid }\end{array}$ \\
\hline
\end{tabular}

Table 3. shows that the developed learning device is very valid with the mean score of $94.8 \%$. Suggestion and feedback obtained from each validation are used as consideration for the revision of prototype 1 .

The results of the improvement from prototype 1 were considered as the prototype II. Improvements within the prototype II that have been made are that (a) in syllabus and lesson plans: GPA was added according to learning objectives, the extension and description for subject matter,; (b) in student worksheet: the questions should be on HOTS level; and (c) in teaching Materials: in which the test has shown high level questions, implicitly the beginning of the chapter has included learning objectives, illustrated images are not proportional, the concept map display to be clarified and the page should be intermittent (left-right).

The testing of the prototype II device was conducted in a limited class, namely in class X MIA SMA Negeri 7 Mataram. The purpose of the trial was to see the effectiveness of developed learning devices for the BBL model. The testing was conducted with the teaching material about "Archaebacteria and Eubacrteria". The data collected in this testing were the results from the questionnaire responses from teachers and students as users, and also from the cognitive learning outcomes of students. The test results can be seen in Table 4 .

TABLE 4. Results FROM TESTING OF DEVELOPED PRODUCT

\begin{tabular}{|c|c|c|c|c|}
\hline \multirow[b]{2}{*}{ Subject } & \multicolumn{3}{|c|}{ User Response } & \multirow{2}{*}{$\begin{array}{c}\text { The Average } \\
\text { Results for } \\
\text { Cognitive Learning }\end{array}$} \\
\hline & PBM & $\begin{array}{l}\text { Teaching } \\
\text { materials }\end{array}$ & LKPD & \\
\hline Teacher & $80.0 \%$ & & & \\
\hline Student & $81.3 \%$ & $81.4 \%$ & $73.0 \%$ & $69.7 \%$ \\
\hline Average & & $78.9 \%$ & & $69.7 \%$ \\
\hline Category & & ctive eno & & Completely enough \\
\hline
\end{tabular}

Table 4. indicates that the developed learning devices were effective enough to be used in learning in class X MIA with an average score of $78.9 \%$. In addition, the result from cognitive learning of students which has an average score of $69.7 \%$ can be categorized into the complete enough category, which means that the learning model for students is neither too good nor too bad. However, to find out more a consistent impact on the model, it is necessary that the developed model to be tested in wider scope of subject or class. However, the results of the development can be seen not only from the point of view of the students but also seen from the responses of teachers and experts.

Based on the results from the test, evaluation and revision stages above, it was found that the average score as the combined validation (V) scores from expert validation (94.8\%), from user validation (78.9\%), and for audience validation $(69.7 \%)$ was $81.1 \%$. With reference to the criteria of effectiveness of the learning model, it can be concluded that the developed learning devices of the BBL model with the scientific approach have achieved the level of effectiveness which is very valid, very effective, very complete and it can be used without improvement.

\section{CONCLUSION}

Based on the results of data analysis and discussion above, it can be concluded that the learning devices for the BBL model which was developed with the scientific approach has the level of effectiveness which indicates very valid, very effective, and very complete and it can be used without any further revision. It is based on the average scores $(81.1 \%)$ obtained from the combined validation (V) from expert validation $(94.8 \%)$, user validation $(78.9 \%)$, and audience validation $(69.7 \%)$.

\section{REFERENCES}

[1] B. S. N. Pendidikan, "Standar isi," Jakarta BSNP, 2006.

[2] G. Hadiprayitno, "Pengaruh Implementasi Perangkat Pembelajaran Biologi Berbasis Potensi Lokal Terhadap Kemampuan Kognitif Peserta Didik," Educatio, vol. 13, no. 2, pp. 84-89, 2018.

[3] W. Kushartanti, "Optimalisasi Otak dalam Sistem Pendidikan Berperadaban," Pidato Dies Natalis, 2004.

[4] A. M. R. Santoso, Right brain for kids: mengembangkan kemampuan otak kanan anak-anak. Gramedia Pustaka Utama, 2002.

[5] C. Bowen, "Resolving the Conflict: Brain-Based Learning, Best Practices, and No Child Left Behind," Perspect. Learn., vol. 12 , no. 1 , p. $6,2011$.

[6] J. Eric, "Pembelajaran Berbasis Otak Paradigma Pengajaran Baru Eds 2," Jakarta PT Indeks, 2011.

[7] M. Ozden and M. Gultekin, "The effects of brain-based learning on academic achievement and retention of knowledge in science course," Electron. J. Res. Sci. Math. Educ., 2008.

[8] E. Jensen, Brain-based learning: The new paradigm of teaching. Corwin Press, 2008.

[9] K. M. Yuntari and I. K. D. G. Raga, "Pengaruh Model Pembelajaran Berbasis Otak (Brain Based Learning) Terhadap Hasil Belajar IPS Siswa Kelas IV di Gugus I Kecamatan Jembrana," Mimb. PGSD Undiksha, vol. 1, no. 1, 2013. 
[10]A. Prawoto, "Pembelajaran dengan pendekatan brain based learning untuk meningkatkan hasil belajar matematika siswa SMP,” Bandung: STKIP Siliwangi, 2011.

[11]N. Munfaridah, "Pengaruh Brain Based Learning Berbatuan Mind Map terhadap Penguasaan Konsep dan Kemampuan Berpikir Kritis Fisika,” Universitas Negeri Malang, 2013.

[12]E. AKYÜREK and Ö. AFACAN, "Effects of Brain-Based Learning Approach on Students' Motivation and Attitudes Levels in Science Class," Mevlana Int. J. Educ., 2013, doi: 10.13054/mije.13.08.3.1

[13]T. Plomp, "Educational design research: An introduction," Educ. Des. Res., pp. 11-50, 2013.

[14]A. U. Rehman and M. A. Bokhari, "Effectiveness of brainbased learning theory at secondary level," Int. J. Acad. Res., vol. 3, no. 4, pp. 354-359, 2011.

[15]J. Ramakrishnan and R. Annakodi, "Brain based learning strategies," Int. J. Innov. Res. Stud., vol. 2, no. 5, pp. 235-242, 2013.

[16]R. Susilana, "Pendekatan saintifik dalam implementasi kurikulum 2013 berdasarkan kajian teori psikologi belajar," Edutech, vol. 13, no. 2, pp. 183-193, 2014.

[17]S. Putrawangsa, Desain Pembelajaran: Design Research Sebagai Pendekatan Desain Pembelajaran. CV. REKA KARYA AMERTA, 2018

[18]L. Harmon, K. Troester, T. Pickwick, and G. Pelosi, "The effects of different types of music on cognitive abilities," $J$. Undergrad. Psychol. Res., vol. 3, pp. 41-46, 2008.

[19]L. D. Kurniawati, I. Ghozali, and A. Wartiningsih, "Pengaruh Musik Klasik Karya WA Mozart Terhadap Kecerdasan Emosional Kelas 5 SDN 06 Pontianak," Progr. Stud. Pendidik. Seni Tari dan Musik FKIP Untan, 2013.

[20]B. S. Handayani and A. D. Corebima, "Model brain based learning (BBL) and whole brain teaching (WBT) in learning," in International Journal of Science and Applied Science: Conference Series, 2017, vol. 1, no. 2, p. 153.

[21]J. van den Akker, R. M. Branch, K. Gustafson, N. Nieveen, and T. Plomp, Design approaches and tools in education and training. Springer Science \& Business Media, 2012. 